\title{
Trade liberalization and trade inflows: A study of Nigeria's economy using ARDL model approach
}

\author{
Justin C. Alugbuo ${ }^{1}$ and Sebastian O. Uremadu ${ }^{2, *}$ \\ ${ }^{1}$ Lecturer, Department of Economics, College of Management Sciences (COLMAS), Michael Okpara University of Agriculture, \\ Umudike, Abia State, Nigeria. \\ ${ }^{2}$ Professor, Department of Banking and Finance, College of Management Sciences (COLMAS), Michael Okpara University of \\ Agriculture, Umudike, Abia State, Nigeria.
}

Publication history: Received on 02 July 2020; revised on 10 July 2020; accepted on 12 July 2020

Article DOI: https://doi.org/10.30574/gscarr.2020.4.1.0057

\begin{abstract}
In Nigeria, despite the success of implementation of trade liberalization measures, and the persistent signs of economic recovery as seen from reduction in external debt and debt service payments, some macroeconomic pointers still showed poor performance of the overall economy and it is against this backdrop, that this study investigated effect of trade liberalization and trade inflows in Nigeria covering the period 1981-2018 with the help of the ARDL model of estimation. Based on the issues covered in the literature review, empirical investigations were carried out on the effect of trade liberalization and trade inflows in the Nigeria. Results showed that trade openness (TOP) had a negative relationship with economic growth in both the current year and in the long run. Similarly, import volume index (IMPVID) had a negative relationship with real gross domestic product (RGDP) for the current year and in the long run, while export volume index (EXPVID) had a positive impact on RGDP but was insignificant in the previous year's lags. The result from the ARDL Bounds Test for co-integration test indicated evidence of long run relationship among the variables of interest while trade openness and RGDP had a non-directional causality between them. Based on these findings, the study recommended that government should encourage import liberalization through reduction in tariff rates, gradual removal of non-tariff barriers (NTB), outright banning of certain goods which will ensure that domestic imports, following trade liberalization, are directed mainly on intermediate and capital goods.
\end{abstract}

Keywords: Trade Liberalization; Trade Inflows; Trade Openness; Economics Growth

\section{Introduction}

\subsection{Background to the study and Statement of the problem}

Over the years, trade was considered as an essential and motor of economic growth for nations which are at different levels of growth [1]. Trade does transform growth from one economy to other economies and contribute to better resource allocations. For many years, there has been a tremendous economic growth in some countries and a fluctuating economy in others and as a result there exists less evidence of convergences [2]. International trade plays a crucial role in the sense that there exist both dynamic and static gains from trade though trade theories do not say anything about the fairness of those gains from trade.

World trade policies are getting deregulated from time to time after the Second World War starting from 1947 when 23 nations had signed the General Agreement on Tariffs and Trades (GATT). The fundamental objective was lowering tariffs significantly and other restrictions. Complement to this GATT was replaced by World Trade Organization (WTO) after the eighth ministerial conference of United Nations held in Uruguay. Between the foundation of GATT and WTO

\footnotetext{
* Corresponding author: Sebastian 0 Uremadu
} 
which has stayed for 50 years, there have been eight different ministerial conferences which all rounds are aimed at avoiding tariff and non-tariff barriers. This was basically considered as a huge step forward towards trade liberalization. Moreover, the world leading financial institutions, International Monetary Fund (IMF) and World Bank, are also the main actors of trade liberalization in the sense that developing countries are supposed to adapt structural adjustment programs in which deregulation of trade policies and other domestic policies were the core principals to get loan.

Trade liberalization and flows within and outside an economy has been a subject of discussion and research among scholars and researchers alike for over seven decades. The idea that trade liberalization or trade openness is one of the most important determinants of economic growth is becoming increasingly popular among governments of less developed countries (LDCS) and Nigeria in particular. Conventional wisdom suggests that openness promotes economic growth. However, while various theoretical models predict that openness to international trade accelerates economic growth, the empirical evidence has been mixed or imprecise [3].

Basically, the main purpose of trade liberalization is to allow countries to export those goods and services that they can be produced efficiently, and import the goods and services that they produce inefficiently. Sequel to the emergence of trade liberalization and trade flows among various economies, it is believed that trade liberalization aids growth, which in turn aids poverty alleviation, but it is required that trade policy, should not, none the less, be manipulated too closely with an eye to direct poverty consequences, it should rather be set on a sound basis over-all [4]; [5].

In recent years, the negative pressure which the volatile capital market of the advanced capitalist economies exerts on the developing countries has given rise to counter opinion which supports the negative aspects of openness and questions are being asked as to whether developing countries actually share in its benefits. In line with the spirit of openness, for instance, the trade and exchange rate policies of Nigeria were conclusively reviewed at the close of 1986. Export duties were cancelled out. Import licensing for many imports were abolished. All of these measures resulted in uninhibited access of imported goods to the Nigerian market without obvious positive impact on domestic production in the manufacturing sector. For instance, between 1985 and 2003, the real exchange rate of the Naira had depreciated by more than $95 \%$ thereby further worsening the terms of trade. The food export-import gap which had reduced in the early part of 1980s has since been widened. According to the Manufacturers' Association of Nigerian's Economic Review, 2001-2002, average capacity utilization in the manufacturing sector only showed dramatic improvement of 41.9 percent in 2001 and 52.5 percent in year 2002 as against 29.7 percent in year 2000. In spite of this improvement, the balance- of- payment was under severe pressure in the year 2002, as a result of, adverse external shocks, particularly the reduction in Nigeria's crude oil production quota by the Organization for Petroleum Exporting Countries (OPEC) and increase in the external service burden.

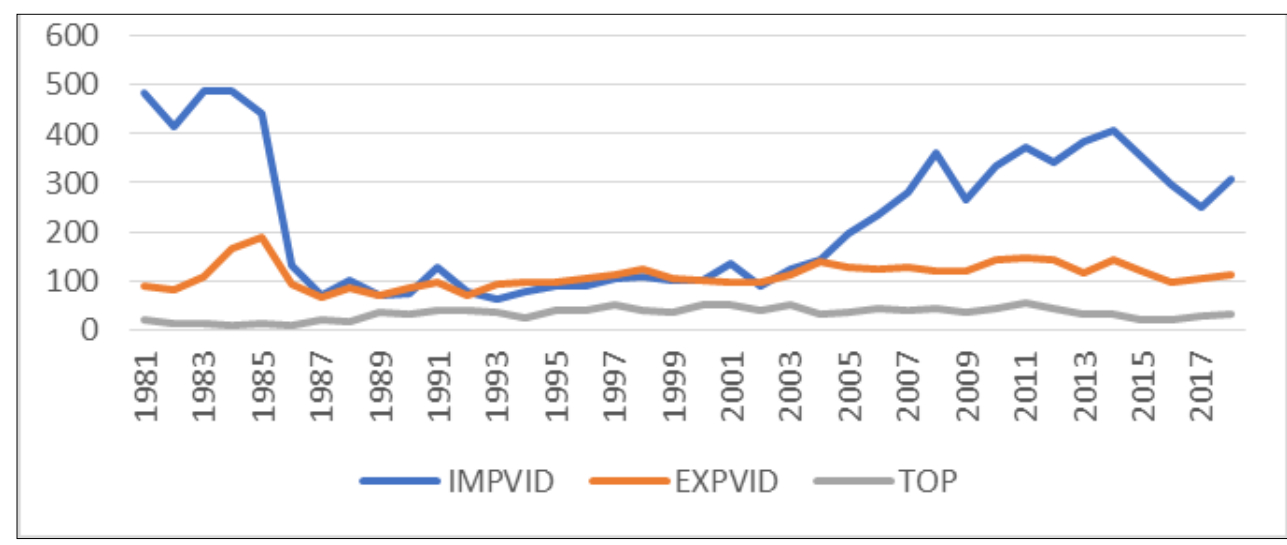

Figure 1 Interaction of import volume index, export volume index and trade openness in Nigeria

Source: Researchers Compilation, 2019

It is still undecided whether trade liberalization and trade inflows affect economic growth positively or negatively for the development of countries. The main purpose of trade liberalization since mid-1980 was to encourage economic growth by capturing the static and dynamic gains from trade through technological transfer and innovation, proper allocation of resources, creating more computation among nations, increasing inflow of investment and capital accumulation. [6], [7], [8], [9], [10], are among those who have argued about the greater opportunity to grasp and absorb 
technological advancement spawned from the developed nations which is the benefits from a positive relationship between trade liberalization and economic growth, others as described in the works of [11] and [12] who concluded that trade liberalization and economic growth are inversely related in the case of developing countries specifically in Africa.

As observed from the graph above, from the year 1981 to 1985, Nigeria imports were the highest but drastically reduced from 1987 down to 2005 and peaked again from 2007 to date. Looking at Export activities, indicated a low export activities as shown in the graph above with a slight increase in 1985 and these combined activities of imports and exports have translated to an inelastic movement of trade openness in the economy of Nigeria.

The issue of opening an economic activity for the international market may trigger a trade performance better than those who closed their economy due to the fact that opening the economy to the international market allows the country to attract foreign direct investment (FDI), create market access for domestically produced goods, technological transfer from other nations through trade especially by importing machineries and skill demanding materials, which in turn creates employment opportunities [13].

Despite the efforts of successive governments in Nigeria in liberalizing trade and its flows in order to enhance the economy, there is a persistent rise in poverty level, business failures and the economy plunging into recession in recent time. According to [14], in Nigeria, despite implementation of trade liberalization measures and the persistent signs of economic recovery as seen from reduction in external debt and debt service payment, some macroeconomic pointers showed poor performances of the overall economy. For instance, the economy has been characterized by low degree of savings accompanied by liquidity trap, capacity underutilization and low rate of capital formation. This poor situation reflects in the high rate of unemployment in the country. The conventional arguments in support of and against international trade are no doubt convincing, but the empirical evidence is yet to be topical especially in Nigeria. Trade liberalization is an essential component of international trade and finance. It entails the removal of the various barriers to trade that countries around the world have erected and has been recognized by many studies as an important factor accounting for the economic growth and development of many nations [15]. Trade liberalization has been a burning issue in Nigeria and ascertaining whether Nigeria's involvement in international trade boosts or hinders economic growth has been a persisting problem thereby warranting an empirical investigation into the study area to ascertain impact of trade liberalization and trade flows in Nigeria.

Trade liberalization is the removal or reduction of restrictions or barriers on the free exchange of goods between nations. This includes the removal or reduction of both tariff (duties and surcharges) and non-tariff obstacles (like licensing rules, quotas and other requirements). The easing or eradication of these restrictions is often referred to as promoting "free trade." It is a policy by which a government does not discriminate against imports or interfere with exports by applying tariffs (to imports) or subsidies (to exports) or quotas. According to the law of comparative advantage, the policy permits trading partner's mutual gains from trade of goods and services [16].

Under a trade liberalization policy, prices emerge from the equilibration of supply and demand, and are the sole determinant of resource allocation. 'Free' trade differs from other forms of trade policy where the allocation of goods and services among trading countries are determined by price strategies that may differ from those that would emerge under deregulation. These governed prices are the result of government intervention in the market through price adjustments or supply restrictions, including protectionist policies. Such government interventions can increase as well as decrease the cost of goods and services to both consumers and producers [17]. Trade openness refers to the degree of dependence of an economy on international trade and financial flows. It measures the international competitiveness of a country in the global market. Thus, we may talk of trade openness and financial openness. Trade openness is often measured by the ratio of the sum of export and import to GDP or alternatively, the ratio of the sum of trade to GDP. It is now generally accepted that increased openness with respect to both trade and capital flows will be beneficial to a country. Increased openness facilities greater integration into global market. Integration and globalization are beneficial to developing countries although there are also some potential risks [18].

Trade openness has also been defined as the ratio of foreign trade (export + import) to the gross domestic product (GDP) of the domestic economy of any country [19]. He states that the higher the index of openness, the larger the impact of trade on the domestic economy. In the opinions of [20], the removal of obstacles to trade (openness); is closely and positively associated with GDP-growth. However, to [21], openness and trade can raise economic growth in some countries but it may also reduce it in other countries depending on the level of development of the country. 
In a related development, foreign direct investment (FDI) is an investment made by an individual or a company (investor) in a country which is not the country of origin of the investor, in the form of either establishing business or acquiring business assets in the country.

Similarly, import has been defined as the amount of goods and services bought from other countries. It is expected that higher imports will lead to lower economic growth. The variable is a leakage or withdrawal in the equilibrium equation of an economy and as such, it contributes negatively to economic growth [22]. In the same vein, [23], define exports as the amount of goods and services sold to other countries. It is expected to induce economic growth as more volume of it means more trade, more production and more income. Besides, it is an injection in the equilibrium equation of the economy.

The theory upon which this study is anchored is the Export led Growth Hypothesis. The theory postulates a relationship between the growth of exports and the economy such that export expansion becomes one of the main determinants of economic growth. The hypothesis holds that overall growth of different economies could be generated not by increasing the amounts of labour and capital, but also by expanding exports. The theoretical rationale for this hypothesis lies on a number of assumptions which include but not limited to the following: one, that the export sector will generate positive externalities on non-export sectors through more efficient management styles and improved production techniques [24]. Two, export expansion will increase productivity by offering potential for scale economies [25]; [26]. Three, exports are likely to alleviate foreign exchange constraints and can provide greater access to international markets [27]. Evidence from literature indicates that the arguments have recently been extended by the literature on endogenous growth theory which emphasizes the role of exports on long-run growth via a high rate of technological innovation and dynamic learning from abroad [28]; [29].

The study has examined some related empirical literature on trade liberalization and trade flows. For example: [30], examined effect of trade liberalization on economic growth in Nigeria, using the Gross domestic product (GDP) as proxy for economic growth. The study made use of a set of data that spanned (1980 - 2015). Ordinary Least Squares (OLS) was used in estimating effect of trade liberalization on economic growth in Nigeria with a view to ascertaining whether long-run relationship exists between the two and also used in verifying for structural change that may have occurred within the implementation period of a free trade regime that started in 1986. Data for the study were sourced from World Development Indicators (WDI) of the World Bank and Statistical Bulletin of the Central Bank of Nigeria (CBN) various issues. Results indicated that liberalization had a positive and significant effect on economic growth in Nigeria, with an evidence of a long-run relationship. Similarly, strong evidence was found to support structural change that took place in 1986 when free trade policy was adopted. The results also presented a violation of the $a$ priori in the case of export and import which showed negative and positive signs, respectively.

[31], examined impact of trade liberalization on performance in the Nigerian economy, with special reference to agricultural and manufacturing sectors. Simultaneous models were developed to capture the joint effects of trade liberalization on the two sectors. The Generalized Method of Moment technique was used to estimate the role of trade liberalization on the performance of the selected sectors. The study showed a positive and significant impact of trade liberalization on the output of agricultural sector while a negative but significant relationship exists between measures of trade liberalization and manufacturing output in Nigeria. The study also revealed that exchange rate exerted a positive but insignificant impact on agricultural output while the effect of inflation on agricultural output was positive and significant within the study period. Unlike the agricultural output, both exchange rate and inflation had negative impact on manufacturing sector's output. Moreover, finding from the study also confirmed the possibility of substantial economic linkage between the two sectors, as their magnitudes were positive and significant which suggested some significant level of interdependence between them in the Nigerian economy.

[32], examined impact of international trade on economic growth in Nigeria, with the objective of identifying the major factors influencing economic growth through international trade using time series secondary data obtained from Central Bank of Nigeria, National Bureau of Statistics and International Financial Statistics for a period between 1981 and 2014. Augmented Dickey-Fuller (ADF) test together with Phillip- Perron (PP) test of Unit Root Tests were employed to ascertain the stationarity properties of the variables. The Ordinary Least Square (OLS) technique was used to test for the significant relationship between the level of economic growth proxied by GDP as dependent variable and exchange rate, government expenditure, interest rate, foreign direct investment, import and export as independent variables. The result revealed that government expenditures, interest rate, import and export were all positively significant while exchange rate and foreign direct investment were negatively insignificant to the growth process of the Nigerian Economy. 
[33], examined trade openness, financial development, and the Nigerian economy. The aim was to investigate the relationship between changes in different variables of trade openness and financial development; and its impact on the growth rate of the Nigerian economy using annual time series data for the period 1981-2013 from the Central Bank of Nigeria to estimate both long and short-run relationship as well as causal effects. The Unit root test showed that the variables were stationary at level and after been first differenced; at the 5\% significance level. The Johansen Co integration test gave evidence of four co-integrating equations which explained that a long-run equilibrium relationship existed among the variables. The Vector Error Correction Model was used to analyze short-run adjustment dynamics and showed $96.7 \%$ speed of adjustment of prior deviations from equilibrium. The Granger Causality test demonstrated both bi-directional causality between real effective exchange rate and total trade; and uni-directional causality from gross domestic product to total trade, gross domestic product to credit to the private sector, total trade to foreign direct investment, total trade to credit to the private sector and real effective exchange rate to foreign direct investment. Furthermore, the Impulse Response and Variance Decomposition test indicated both positive and negative shocks which are consistent with the findings from the vector error correction model and Granger causality analyses. Overall, all the results obtained were in line with a-priori expectations.

[34] Examined impact of international trade on economic growth in Nigeria (1988-2012) using net export (i.e total export less total import) and balance of payment as proxies for international trade while gross domestic product represent economic growth. The study employed regression analysis as the method of analysis using co-integration and error correction modeling techniques to find the long-run relationship between economic performance and international trade. Only total export (TEX) remained positive and significant while others remained insignificant, which meant that Nigeria was running a monoculture economy where only oil act as the sole support of the economy without tangible support from other sectors such as industrial, manufacturing and agriculture.

[15] Investigated trade liberalization and economic growth: The Nigerian experience (1971-2012) using Ordinary Least Squares (OLS) regression technique. The results provided clear indication that imports and exports significantly and positively affected economic growth in Nigeria.

\section{Methodology}

\subsection{Research design}

Macro-economic modeling is generally motivated by two objectives: forecasting and more significantly, policy analysis. In pursuit of these objectives, every model should ideally satisfy four (4) criteria. First, it must fit into a theoretical framework, second, the specification of the model must reflect a clear understanding of the conceptual framework within which policies are formulated and executed along with an envisaged process of adjustment. Third, it is essential that the model is built on a firm and rich data base and finally, the estimated structural model must adequately utilize the rigors and sophistication of econometric methodology.

\subsection{Model specification}

The model for this study is anchored on the Export led Growth Hypothesis which postulates a relationship between the growth of exports and the economy such that export expansion becomes one of the main determinants of economic growth. The hypothesis holds that overall growth of different economies could be generated not by increasing the amounts of labour and capital, but also by expanding exports. The model construction for this study is therefore fashioned according to the work of [15] below:

GDP (Y) f (EXP, IMP, TOP) .I

To address the main objective, the model in equation one is modified as follows:

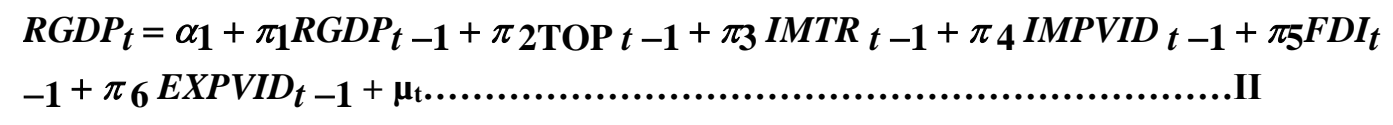

Where: RGDP = Real Gross Domestic Product (A proxy for economic growth)

TOP = Trade Openness (A proxy for trade liberalization and trade inflows)

IMTR = Import Tariffs

IMPVID = Import Volume Index

FDI = Foreign Direct Investment 
EXPVID = Export Volume Index

$\pi_{1}$ to $\pi_{6}=$ coefficients of the long-run parameters

$\Delta=$ first difference operator

$t-1$ = lag order selected by Akaike's Information Criterion (AIC

The study utilized the Auto-Regressive Distributed Lag (ARDL) bounds test approach developed by [36], to investigate effect of trade liberalization and trade inflows in Nigeria. The procedure for the ARDL bounds testing approach has two steps. The first step is testing for long-run relationship using OLS and the next step is the estimation of short-run parameters by using the unrestricted error correction model (UECM). A dynamic unrestricted error correction model (UECM) can be derived from the ARDL bounds testing by way of a simple linear transformation. The UECM integrates the short-run dynamics with the long-run equilibrium without losing any long-run information. Therefore, equation 3.2 is the ARDL-UECM specification as follows:

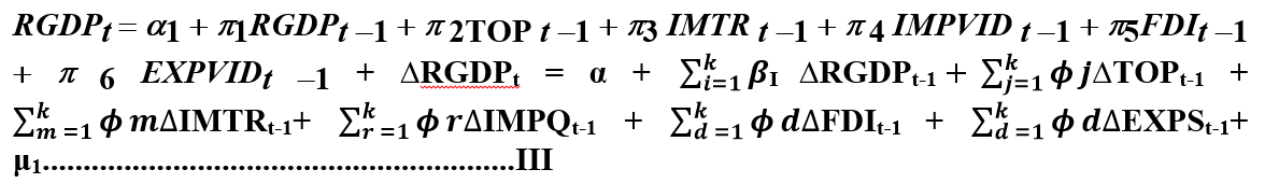

\section{Results}

\subsection{Descriptive statistics}

Preliminary analysis was conducted with the aim to determine the normality of the data, measures of central tendency and measures of dispersion. The mean and median are measures of central tendency and they indicate the average value of the sample. Standard deviation is the positive square root of variance. It is a measure of dispersion, that is, it shows the extent of the deviation from the mean. The null hypothesis of the Jarque-Bera test says that the distribution is a normal one. Therefore if the probability is less than 0.05 , we reject the null hypothesis.

Table 1 Common sample descriptive statistics

\begin{tabular}{lllllll}
\hline & LRGDP & TOP & LIMPTR & LFDI & IMPVID & EXPVID \\
\hline Mean & 4.459743 & 32.23791 & 10.14771 & 9.216542 & 225.8184 & 110.6850 \\
Median & 4.362869 & 33.95119 & 10.14588 & 9.237562 & 170.6929 & 107.3192 \\
Maximum & 4.843918 & 53.27796 & 10.94882 & 9.946507 & 489.5706 & 187.6372 \\
Minimum & 4.139226 & 9.135846 & 9.328414 & 8.276840 & 62.86181 & 67.36635 \\
Std. Dev. & 0.243724 & 12.56403 & 0.505473 & 0.467915 & 144.0398 & 26.26857 \\
Skewness & 0.344411 & -0.348759 & -0.017456 & -0.161014 & 0.447239 & 0.709198 \\
Kurtosis & 1.630051 & 2.189736 & 1.673294 & 2.113061 & 1.724326 & 3.556063 \\
Jarque-Bera & 3.722790 & 1.809843 & 2.788831 & 1.409742 & 3.843438 & 3.674998 \\
Probability & 0.155456 & 0.404574 & 0.247978 & 0.494172 & 0.146355 & 0.159215 \\
\hline
\end{tabular}

From table 1, it could be seen that all the variables i.e LRGDP. LFDI, TOP, IMTR, IMPVID, and EXPVID had p-values greater than 0.05 signifying that they were normally distributed.

\subsection{Unit root test}

In order to verify the reliability of the time series data used for this analysis, a unit root test was conducted on the selected time series data to determine whether they are stationary or non-stationary in level form. The unit root test that was employed in this task is the Augmented Dickey Fuller unit root test. The result of the ADF Test is presented below: 
Table 2 Summary of unit root test

\begin{tabular}{llllll}
\hline VARAIBLE & $\begin{array}{l}\text { ADF } \\
\text { (LEVELS) }\end{array}$ & $\begin{array}{l}\text { 5\% critical } \\
\text { value }\end{array}$ & $\begin{array}{l}\text { ADF.Stat. } \\
\text { FIRST DIFFERENCE }\end{array}$ & $\begin{array}{l}\text { 5\% critical } \\
\text { value }\end{array}$ & REMARK \\
\hline LRGDP & -0.027819 & -2.945842 & $-3.395053^{*}$ & -2.945842 & @I(1) \\
LIMPTR & $-4.073897^{*}$ & -3.536601 & & & @I(0) \\
TOP & -2.272949 & -2.943427 & $-7.372908^{*}$ & -2.945842 & @I(1) \\
IMPVID & -2.268090 & -3.536601 & $-5.317438^{*}$ & -3.540328 & @I(1) \\
EXPVID & $-3.106648^{*}$ & -2.943427 & & & @I(0) \\
LFDI & -1.743700 & -2.943427 & $-10.96698^{*}$ & -2.945842 & @I(1) \\
\hline \multicolumn{7}{l}{ Source: Researcher's Compilation from Eviews 10 Regression Output $(2019)}$. & \\
\end{tabular}

From the stationarity test result on Table 2 above, showed that LRGDP, LFDI, TOP, IMPVID were all stationary at first difference since their ADF Test statistics were greater than their tabulated ADF values at 5\% level of significance while LIMPTR, and EXPVID achieved stationarity at level at 5\% level of significance.

The application of unit root tests in autoregressive distributed lag (ARDL) technique is necessary in order to ensure that the variables are integrated of order one and none of the variables is integrated of order 2 because the computed Fstatistic provided by [35], are valid for only variables that are I(0) or I(1) and a combination of both. The outcome of the unit root test in Table 3.3 above indicated that the logged series for all the variables were integrated of order one except Import Tariff (LIMPTR) which was integrated of order zero. Therefore, the variables under study are of mixed integration order and this justified the use of ARDL bounds test approach to co-integration over other conventional approaches that require the variables to be integrated of the same order.

\subsection{Vector autoregressive lag length criteria}

Table 3 Lag length selection criteria

\begin{tabular}{lllllll}
\hline Lag & LogL & LR & FPE & AIC & SC & HQ \\
\hline 0 & -416.1062 & NA & 2446.988 & 24.82977 & 25.09913 & 24.92163 \\
1 & -274.9107 & $224.2517^{*}$ & 5.208877 & 18.64180 & $20.52731^{*}$ & 19.28481 \\
2 & -242.4429 & 40.10726 & 7.907682 & 18.84958 & 22.35123 & 20.04374 \\
3 & -205.6239 & 32.48738 & 14.03717 & 18.80140 & 23.91920 & 20.54672 \\
4 & -119.6509 & 45.51508 & $3.643354^{*}$ & $15.86182^{*}$ & 22.59576 & $18.15829^{*}$ \\
\hline \multicolumn{5}{c}{ Source: Researcher's Extract from Eviews 10 Output }
\end{tabular}

Using the Vector Autoregressive Lag Length Criteria, it enables us to determine the appropriate lag periods in evaluating and estimating the various test for our model. Observing the lag length criteria above, it is obvious that the dominating and appropriate lag for the model is lag period 4. The study will therefore make use of the AIC i.e Akaike Information Criterion for estimation.

\subsection{Autoregressive distributed lag bounds test for co-integration}

Table 4 Result of ARDL bounds test for co-integration

\begin{tabular}{|c|c|c|c|c|}
\hline \multicolumn{2}{|c|}{ F-Bounds Test } & \multicolumn{3}{|c|}{ Null Hypothesis: No levels relationship } \\
\hline \multirow[t]{2}{*}{ Test Statistic } & Value & Signif. & $\mathrm{I}(0)$ & $\mathrm{I}(1)$ \\
\hline & & & Asym & \\
\hline F-statistic & 5.629039 & $10 \%$ & 2.26 & 3.35 \\
\hline \multirow[t]{3}{*}{$\mathrm{k}$} & 5 & $5 \%$ & 2.62 & 3.79 \\
\hline & & $2.5 \%$ & 2.96 & 4.18 \\
\hline & & $1 \%$ & 3.41 & 4.68 \\
\hline
\end{tabular}


From the ARDL Bounds test and going by the decision rule of the Bounds Test, the study cannot accept the null hypothesis of no co-integration since the F-Bounds Statistic of 5.629039 was greater than the I ( 0 ) and I (1) bounds at $10 \%, 5 \%$ and $1 \%$ respectively, therefore we conclude that there exists a long run relationship among the variables.

\subsection{Interpretation of results}

\subsubsection{Dynamic short run error correction model}

The Distributive lag and Short Run Estimates of the Model is summarized below:

Table 5 Result of Dynamic Short Run Estimates of the Model for Trade Liberation and Inflows in Nigeria

\begin{tabular}{|c|c|c|c|c|}
\hline \multicolumn{5}{|l|}{ ECM Regression } \\
\hline Variable & Coefficient & Std. Error & t-Statistic & Prob. \\
\hline $\mathrm{C}$ & -0.216830 & 0.033604 & -6.452418 & $0.0000^{*}$ \\
\hline D(LRGDP(-1)) & 0.168391 & 0.117724 & 1.430389 & 0.1745 \\
\hline D(LFDI) & 0.007938 & 0.008180 & 0.970297 & 0.3484 \\
\hline D(LFDI $(-1))$ & 0.058047 & 0.010242 & 5.667845 & $0.0001^{* *}$ \\
\hline D(LFDI $(-2))$ & 0.033582 & 0.011661 & 2.879823 & $0.0121^{* *}$ \\
\hline D(LFDI $(-3))$ & 0.020873 & 0.008744 & 2.387266 & $0.0316^{* *}$ \\
\hline D(IMPVID) & $-3.18 E-05$ & $4.05 \mathrm{E}-05$ & -0.784506 & 0.4458 \\
\hline $\mathrm{D}(\mathrm{TOP})$ & -0.000614 & 0.000380 & -1.617637 & 0.1280 \\
\hline D(LIMPTR) & 0.066067 & 0.015373 & 4.297679 & $0.0007^{* *}$ \\
\hline D(LIMPTR(-1)) & -0.080885 & 0.018235 & -4.435793 & $0.0006^{* *}$ \\
\hline D(LIMPTR(-2)) & -0.063718 & 0.012660 & -5.033115 & $0.0002^{* *}$ \\
\hline D(LIMPTR(-3)) & -0.049381 & 0.014402 & -3.428634 & $0.0041^{* *}$ \\
\hline D(EXPVID) & 0.000150 & $8.52 \mathrm{E}-05$ & 1.755421 & 0.1010 \\
\hline D(EXPVID(-1)) & $-2.02 \mathrm{E}-05$ & $6.97 \mathrm{E}-05$ & -0.289393 & 0.7765 \\
\hline D(EXPVID(-2)) & 7.37E-06 & $6.42 \mathrm{E}-05$ & 0.114876 & 0.9102 \\
\hline D(EXPVID(-3)) & -0.000212 & $6.67 \mathrm{E}-05$ & -3.180603 & $0.0067^{* *}$ \\
\hline CointEq $(-1)^{*}$ & -0.319296 & 0.047162 & -6.770263 & $0.0000 *$ \\
\hline
\end{tabular}

From the dynamic short regression result above, the coefficient of the constant term (C) was negative and significant and did not conforms to a priori expectation. The value of the constant term was -0.216830 and this showed that when other explanatory variables are held constant, RGDP will decrease by 0.216830 units.

Analysis of the short run coefficients showed that real gross domestic product (LRGDP) was positive in the previous one year lag period, increasing itself by 0.168391 units.

Foreign direct investment had a positive coefficient of 0.007938 units, implying a positive relationship with RGDP in the current year but statistically insignificant at 5\% level of significance although showed to be a strong contributor to RGDP as evidenced in the previous year's lags of year 1, 2 \& 3 and this implied that previous increases in FDI will increase RGDP significantly by $0.058047,0.033582$ and 0.020873 units, respectively.

Furthermore, import volume index (IMPVID) was negative for the current year and one year lag period decreasing RGDP significantly by 0.0000318 units and this implied that for every increase in Import, RGDP significantly decreased by 0.0000318 units. Similarly, Trade openness was found to have a negative co-efficient with RGDP in the current year, 
decreasing RGDP significantly by 0.000614 units implying that for every increase in TOP, RGDP decreased by 0.000614 units.

Import tariff (LIMPTR) is positively impacting on RGDP, increasing RGDP by 0.066067 units significantly in the current year even though it was found not to be a strong contributor to RGDP in the previous years of lag period one, two and three, decreasing RGDP significantly by 0.080885 units, 0.063718 units and 0.049381 units, respectively.

Similarly, export volume index (EXPVID) was positively impacting on RGDP by increasing RGDP by 0.000150 units but its impact was insignificant at 5\% level of significance as also evidenced in the previous year lags.

Finally, the error correction mechanism met the required conditions. The significance and rule of ECM holds that negative and statistical significant error correction coefficients are necessary conditions for any disequilibrium to be corrected. In light of this, the coefficient of CointEq (-1) is -0.319296 . The above result showed that the ECM $(-1)$ value was $-0.32 \%$ implying that there was convergence of the equilibrium should there be system disequilibrium. The negative sign of the coefficient satisfied one condition while the fact that its P-value [0.0000] was less than 5\% [0.05] level of significance satisfied the second condition of statistical significance. The coefficient indicated that the speed of adjustment between the short run dynamics and the long run equilibrium was 32\%. Thus, ECM will adequately act to correct any deviations of the short run dynamics to its long-run equilibrium by $32 \%$ annually. This means that if RGDP is at disequilibrium, it converges back to equilibrium at an average speed of about $32 \%(0.319296 \times 100)$ every year in Nigeria.

\subsubsection{Static long run estimates of trade liberalization and trade inflows in Nigeria.}

Table 6 Result of Static Long Run Estimates Model for Trade Liberation and Inflows in Nigeria

\begin{tabular}{|c|c|c|c|c|}
\hline Variable & Coefficient & Std. Error & t-Statistic & Prob. \\
\hline LFDI & -0.081504 & 0.070877 & -1.149937 & 0.2694 \\
\hline LIMPTR & 0.602420 & 0.062342 & 9.663229 & $0.0000^{*}$ \\
\hline IMPVID & $-9.96 \mathrm{E}-05$ & 0.000127 & -0.782273 & 0.4471 \\
\hline EXPVID & -0.000614 & 0.000731 & -0.839739 & 0.4152 \\
\hline TOP & -0.001924 & 0.001027 & -1.872612 & 0.0822 \\
\hline \multicolumn{5}{|l|}{ R-squared $=0.999392 \approx 100 \%$} \\
\hline \multicolumn{5}{|l|}{ Adjusted R-squared $=0.998566 \approx 100 \%$} \\
\hline \multicolumn{5}{|l|}{ F-statistic $=1210.490$} \\
\hline Prob (F-statistic) & & & & \\
\hline Durbin-Watson stat $=2.523602$ & & & & \\
\hline
\end{tabular}

Foreign Direct Investment (LFDI): The long run estimates of foreign direct investment (LFDI) had a negative relationship with RGDP in the long run decreasing it insignificantly by 0.081504 units at $5 \%$ level of significance.

Import Tariff (LIMPTR): The long run estimates of import Tariff (LIMPTR) had a positive relationship with RGDP in the long run, increasing it significantly by 0.602420 units at $5 \%$ level of significance.

Import Volume Index (IMPVID): The long run estimates of Import volume (IMPVID) had a negative relationship with RGDP in the long run, decreasing it insignificantly by 0.0000996 units at $5 \%$ level of significance.

Export Volume Index (EXPVID): The long run estimate of export volume index (EXPVID) had a negative relationship with RGDP in the long run, decreasing it insignificantly by 0.000614 units at $5 \%$ level of significance.

Trade Openness (TOP): The long run estimates of trade openness (TOP) had a negative relationship with RGDP in the long run, decreasing it insignificantly by 0.001924 units at $5 \%$ level of significance. 
Finally, R-Square indicated that $99 \%$ of the total variation in real gross domestic product is accounted for by trade openness (TOP), import tariff (LIMPTR), import volume index (IMPVID), export volume index (EXPVID) and foreign direct investment (LFDI), however, the total variation of $1 \%$ in the dependent variable is attributable to the influence of other factors not included in the regression model.

\subsection{Diagnostic Test/Post Estimation Test}

\subsubsection{Test for autocorrelation}

Durbin Watson $(\mathrm{DW})=2.523602$

Decision: Since the value of Durbin Watson $=2.523602$ and clearly above to 2 , the study therefore concluded and accepted $\mathrm{H}_{0}$ that there was no autocorrelation present in the Model.

\subsubsection{Heteroscedasticity Test}

Heteroscedasticity is the violation of the ordinary least square. Regression assumption states that the variance of the Error terms are homoscedastic that is, the error terms have a constant variance. Simply put, heteroskedasticity occurs when the variance of the error terms are not constant for all values of X.

Table 7 Result of Heteroscedasticity Test for Trade Liberation and Inflows in Nigeria

\begin{tabular}{|c|c|c|c|}
\hline \multicolumn{4}{|c|}{ Heteroskedasticity Test: ARCH } \\
\hline F-statistic & 0.058195 & Prob. $F(1,31)$ & 0.8110 \\
\hline Obs*R-squared & 0.061834 & Prob. Chi-Square(1) & 0.8036 \\
\hline
\end{tabular}

Considering the Heteroscedasticity table above, the study cannot reject the null hypothesis since the Prob Value is $0.8110>0.05$ level of Significance indicating no presence of Heteroscedasticity in the model.

\subsubsection{Stability Test}

The cusum test and cusum of squares for model stability was employed to check for the stability of the parameters in the model. The result of the stability test is shown below:



Figure 2 Cusum Test for Model Stabilty 




Figure 3 Cusum of Squares for Model Stability

The diagram shows that the model is stable as the cusum line lies in between the $5 \%$ boundary.

\subsubsection{Pairwise granger causality test}

To ascertain the causality between trade openness and RGDP, the study made use of the pairwise granger causality test below:

Table 8 Result of Pairwise Granger Causality Test

\begin{tabular}{|c|c|c|c|}
\hline TOP does not Granger Cause LRGDP & 34 & 1.15808 & 0.3529 \\
\hline LRGDP does not Granger Cause TOP & & 0.24148 & 0.9121 \\
\hline
\end{tabular}

Since study focus is on the direction of causality between trade openness (TOP) and economic growth (RGDP), it therefore concluded that trade openness did not Granger cause economic growth since it had prob-value of $0.3529>$ 0.05 . Also, RGDP did not granger cause TOP with the prob-value of $0.9121>0.05$ and this implied that the direction of causality between TOP and RGDP was non-directional for the period under review.

\subsection{Discussion of findings}

\subsubsection{Effect of trade openness on economic growth in Nigeria.}

Trade openness was found to have a negative co-efficient with economic growth in the current year, decreasing RGDP significantly by 0.000614 units at $5 \%$ level of significance in the short run and was also an insignificant contributor to economic growth in the long run. This latest finding does not conform to a-priori expectation since the extent at which an economy is open for trade transforms to growth of that economy. More also, the finding is not surprising since there seem to be a disequilibrium between import and export activities in Nigeria whereby imports of various goods increases everyday thereby reducing the flow of capital accumulation and improving the economy of the other economies. However, [36] laid support to this finding when the empirically examined the trade and capital flow channels of globalization on macroeconomic stability as proxy by real output growth rate in Nigeria between 1970 and 2009 , their study found trade openness and capital flow dimensions to decline the macroeconomic stability level in Nigeria. This finding also gives credence to the works of [37] and [38] that found an insignificant effect of trade liberalization on the economy of Nigeria.

\subsubsection{Effect of import tariffs on economic growth in Nigeria}

Import tariff (LIMPTR) was found to positively contribute to the growth of the Nigeria economy, increasing RGDP by 0.066067 units significantly in the current year even though it was found not to be a very strong contributor to RGDP in the previous years. In the long Run, Import tariff was also found to have a strong influence positively and significantly to the growth of the Nigeria economy at $5 \%$ level of significance. High tariff, increases government revenues that can be 
used to the benefit of the economy and also motivating the local industries which in turn will bring about economic prosperity.

\subsubsection{Effect of import volume Index on economic growth in Nigeria}

Import volume index (IMPVID) had a negative relationship with RGDP for the current year and one year lag period and also found to have an insignificant impact on economic growth of Nigeria at $5 \%$ level of significance. This finding can be attributed to several factors such as lack of capacity to take advantage of advance technologies embodied in the imported capital goods, inability to sustain installed manufacturing capacity and corrupt practices in procurement processes associated with contracts for the importation of manufactured and capital goods for most failed capital projects.

\subsubsection{Effect of foreign direct investment on economic growth in Nigeria}

Foreign direct investment (FDI) had a positive coefficient of 0.007938 units, implying a positive relationship with RGDP in the current year but statistically insignificant at 5\% level of significance although showed to be a strong contributor to RGDP as evidenced in the previous year's lags in the short run and was also found to have an insignificant negative relationship with RGDP in the long run. This mixed result is consistent with the work of [39] who examined whether or not there is a long run relationship between FDI and economic growth in Nigeria from 1970 to 2010 using co-integration analysis and found out that there is no long run relationship between FDI and economic growth in Nigeria. In the same vein, [40] adopted the ordinary least squares (OLS) estimation technique to analyze the impact of FDI on economic growth in Nigeria and found that FDI is an engine of growth in Nigeria while [41], used the OLS regression technique to examine the impact of foreign direct investment on economic growth in Nigeria from 1970 to 2007 and found no evidence of a strong link between FDI and economic growth. Based on this findings, one can conclude that FDI which shows the net outflows of investment from the reporting economy to the rest of the world has not been optimally utilized.

\subsubsection{Effect of export volume index on economic growth in Nigeria}

Export volume index (EXPVID) had a positive impact on RGDP by increasing RGDP by 0.000150 units but its impact is insignificant at $5 \%$ level of significance as also evidenced in the previous year lags in the short run but show a very weak insignificant impact on the growth of the Nigeria economy in long run and this finding is consistent with the work of [42], who used Granger causality and co-integration tests to investigate the relationship between export, domestic demand and economic growth in Nigeria. The results from Trace and Maximum Eigen Value test conducted showed that the variables do not have long-run relationship, but the Pair-wise Granger Causality test showed that economic growth Granger causes both export and domestic demand, while a bilateral causality exists between export and domestic demand.

\section{Recommendations for policy implementation}

- In this era of globalization, the current Trade liberalization policy should be sustained, but must be fortified with control mechanisms to ensure zero tolerance for corrupt practices (corruption proof). This will eliminate or at least reduce to the barest minimum the rate at which fake, inferior and sub-standard goods, that are of no value in their countries of make, are exchanged for our hard earned foreign exchange. Such policies should incorporate severe sanctions for the economic saboteur.

- Government should encourage import liberalization through reduction in tariff rates, gradual removal of NonTariff Barriers (NTB), outright banning of certain goods which will ensure that our imports, following trade liberalization, is directed mainly on intermediate and capital goods. Imports of consumables would be brought to nil and therefore there would be a corresponding increase in the production of competitive import. Consequently, a higher component of intermediate and capital goods in total import will bring about an improvement in the production of tradable goods, which in turn can provoke increase in exports. This by implication would increase the level of export in the country thereby leading to economic growth in the country.

Finally, the government should vigorously seek to improve the international stand of the economy with other economies of the world so as to enlarge the market for Nigerian exports. It should also re-orient its policy towards the external sector and ensure that the sector contribute optimally to output growth. 


\section{Conclusion}

The study investigated effect of trade liberalization and trade inflows in Nigeria covering the period 1981 to 2018 with the help of the ARDL model of estimation. For the period under review, the outcome of the findings of the study is as follows:

- Trade openness has a negative relationship with economic growth in the current year at $5 \%$ level of significance in the short run and was also an insignificant contributor to economic growth in the long run.

- The study also establishes for the period under review, Import tariff positively contributes to the growth of the Nigeria economy in the current year and also in the long Run at 5\% level of significance.

- Import Volume Index (IMPVID) has a negative relationship with RGDP for the current year and one year lag period and also in the long run had at $5 \%$ level of significance.

- Foreign Direct Investment (FDI) has a positive relationship with RGDP in the current year but statistically insignificant at $5 \%$ level of significance although showed to be a strong contributor to RGDP as evidenced in the previous year's lags.

- Export Volume Index (EXPVID) has a positive impact on RGDP but its impact is insignificant at 5\% level of significance as also evidenced in the previous year lags in the short run but showed a very weak insignificant impact on the growth of the Nigeria economy in long run.

- For the period under review, trade openness does not granger cause economic growth and RGDP does not granger cause trade openness implying a non-directional causality.

- The result the Error Correction Model ( -1 ) value was $-0.32 \%$ implying that there would be convergence to equilibrium should there be system disequilibrium at $32 \%$ correction annually.

Therefore, the conclusion to be drawn from this study is that trade openness (trade liberalization) has an insignificant economic effect on the Nigeria economy in the presence of other internal and external macro-economic shocks. Nevertheless, to achieve a high and sustainable growth, we proffer some policy recommendation which when properly implemented, will surely stimulate greater growth of output.

\section{Compliance with ethical standards}

\section{Acknowledgments}

The authors would like to express their gratitude to all those who must have contributed in one way or the other to the execution of this study.

\section{Disclosure of conflict of interest}

The authors declare no potential conflicts of interest with respect to the research, authorship, and or publication of this article.

\section{References}

[1] Echekoba FN, Okonkwo VI and Adigwe PK. (2015). Trade liberalization and economic growth: The nigerian experience (1971-2012). Journal of Poverty, Investment and Development, 14, 51-72.

[2] Edwards S. (1998). Openness, Productivity and Growth: What Do We Really Know?The Economic Journal, 108(447), 383-398.

[3] Eleanya KN. (2013). Openness and Economic Growth in Nigeria. Journal of Education and Practice, 4(1), 68-73.

[4] Ijeoma NB. (2013). Trade Liberalization in Nigeria: An Examination of Impact and Policy Strategies. International Journal of Scientific \& Engineering Research, 4(12), 1277-1283.

[5] Winters A. (2002). Trade Policies for Poverty Alleviation. In Hoekman, Bernard, Mattoo, Aaditya and English, Philip (eds). Development, Trade and the WTO, A Handbook. World Bank, Washington D.C.

[6] Babatunde MA. (2009). Can Trade Liberalization Stimulate Export Performancein Sub-Sahran Africa. Journal of International and Global Economic Studies, 2(1), 68-92.

[7] Greenway MD, Wynn C and Wright P. (2002). Trade Liberalization and Growth in Developing Countries. Journal of Development Economics, 67(1), 229-244. 
[8] Felix A. (2014). The Impact of Trade Liberalization on Economic Growth in Tanzania. International Journal of Academic Research in Business and Social Sciences, 4(5), 514-532.

[9] Grossman G and Helpman E. (1995). Technology and Trade. Handbook of International Economics, Vol Ill, 12791337.

[10] Mkubwa M, Mtengwa H and Babiker SA. (2014). The Impact of Trade Liberalization on Economic Growth in Tanzania, International Journal of Academic Research in Business and Social Sciences, 4(5), 514-532.

[11] Vaquez D. (2002). Institution, Trade and Growth: Revisiting the Evidence. Journal of Monetary Economics, 50, 133-162.

[12] Winters AL. (2004). Trade Liberalization and Economic Performance: An overview. The Economic Journal, 114 USA.

[13] Parikh A and Stirbu C. (2004). Relationship between Trade Liberalization, Economic Growth and Trade Balance: Hamburgisches Welt-Wirtschafts-Archiv (HWWA).

[14] Umoru D. (2013). Trade Liberalization and Industrial Growth in Nigeria. Journal of Poverty, Investment and Development, 1, 148-156.

[15] Echekoba FN, Okonkwo VI and Adigwe PK (2015). Trade liberalization and economic growth: The Nigerian experience (1971-2012). Journal of Poverty, Investment and Development, 14, 51-72.

[16] Ikenson DJ. (2006). Bhagwati versus Bhagwati on Trade Liberalization. Cato at Liberty: Cato Institute.

[17] Bhagwati J. (2010). Fair Trade versus Free Trade: The American Interest. Greenway, P et al (1998), Iran: Lonely Planet Publications.

[18] Iyoha M and Oriakhi L. (2002). 'Explained African Economic Growth Performance: the case of Nigeria', African Economic Research Consortium. Nairobi

[19] Okpako GU. (2005). Public finance, Ikeja: Tivolick.

[20] Atoyebi KO, Akinde JO, Adekunle FO and Edun F. (2012). Foreign trade and economic growth in Nigeria: an empirical analysis. American Academic and Scholarly Research Journal, 4(5), 211-223.

[21] Utkulu. (2004). Does Trade Liberalization Cause a Long Run Economic Growth in Turkey, Economic Change and Restructuring, 37(3), 245-266.

[22] Nwosa PI, Saibu MO and Fakunle 00. (2012). The effect of trade liberalization on trade tax revenue in Nigeria. African Economic and Business Review, 10(2), 28-43.

[23] Manni UH and Ibne Afzal MN. (2012). Effect of trade liberalization on economic growth of developing countries: A case of Bangladesh economy. Journal of Business, Economics and Finance, 1(2).

[24] Feder G. (1983). Exports and Economic Growth. Journal of Development Economics, 12, 59-73.

[25] Helpman E and Krugman PR. (1985). Market structures and foreign trade. Cambridge: MIT Press.

[26] Krugman P. (1994). The Myth of Asia's Miracle. Foreign Affairs (Nov-Dec), 62- 78.

[27] Esfahani HS. (1991). Exports, Imports and Economic Growth in Semi-Industrial Countries. Journal of Development Economics, 35, 93-116.

[28] Lucas RE. (1988). On the Mechanics of Economic Development. Journal of Monetary Economics, 2(2), 3-42.

[29] Alisna A and Rodrik D. (1999). Distributive Politics and Economic Growth. Quarterly Journal of Economics, 109, 443-465.

[30] Ejike DC, Anah SA and Onwuchekwa FC. (2018). Trade Liberalization and Economic Growth in Nigeria: A Cointegration Analysis (1980-2015). IJRDO -Journal of Business Management, 4(5), 81-94.

[31] Ojeyinka TA and Adegboye AA. (2017). Trade Liberalization and Economic Performance in Nigeria: Evidence from Agricultural and Manufacturing sectors. African Journal of Economic Review, 5(3), 1-14.

[32] Afolabi B, Danladi JD and Azeez MI. (2017). International Trade and Economic Growth in Nigeria. Global Journal of Human-Social Science: Economics, 17(5), 29-39.

[33] Nwinee BF and Olulu-Briggs OV. (2016). Trade Openness, Financial Development, and the Nigerian Economy. American International Journal of Contemporary Research, 6(3), 170- 183. 
[34] Adeleye JO, Adeteye OS and Adewuyi MO. (2015). Impact of International Trade on Economic Growth in Nigeria (1988-2012). International Journal of Financial Research, 6(3), 163-172.

[35] Pesaran MH and Y Shin. (1995). Long-Run Structural Modeling un-published manuscript, University of Cambridge.

[36] Ajayi FO and Atanda AA. (2012). Monetary policy and bank performance in Nigeria: A two-step co-integration approach, African Journal of Scientific Research, 9(1), $462-476$.

[37] Monisola OJ. (2014). Public Policy and Trade Liberalization in Nigerian Economic Development. Research on Humanities and Social Sciences, 4(15), 91-96.

[38] Soi N. (2013). Effect of International Trade on Economic Growth in Kenya. European Journal of Business and Management, 5(10), 131-137.

[39] Olatunji L and Shahid MC. (2014). FDI and Economic Growth in Nigeria: A co-Integration Analysis. Business and Economic Research, 5(1), 243-261.

[40] Adeleke KM, Oluwe SO and Fasesin 00. (2014).Impact of Foreign Direct Investment on Nigerian Economic Growth. International Journal of Academic Research in Business and Social Science, 4(8).

[41] Olukoyo FO. (2012). Foreign DirectInvestment and Economic Growth: A Case of Nigeria. Bvimere's Journal of Management Research, 4(1).

[42] Omoke PC and Ugwuanyi CU. (2010). -Export, Domestic demand and Economic Growth in Nigeria: Granger Causality Analysis. European Journal of Social Sciences, 13(2).

\section{How to cite this article}

Justin CA and Sebastian OU. (2020). Trade liberalization and trade inflows: A Study of Nigeria's Economy using ARDL Model Approach. GSC Advanced Research and Reviews, 4(1), 31-45. 